\title{
Lactation performance of dairy cows fed rehydrated and ensiled corn grain differing in particle size and proportion in the diet
}

\author{
Lucas P. Castro, ${ }^{1}$ Marcos N. Pereira, ${ }^{1,2 *}$ Julia D. L. Dias, ${ }^{1}$ Douglas V. D. Lage, ${ }^{1}$ Eugenio F. Barbosa, ${ }^{1}$ \\ Ricardo P. Melo, ${ }^{1}$ Karla Ferreira, ${ }^{1}$ Josué T. R. Carvalho, ${ }^{1}$ Fabiana F. Cardoso, ${ }^{1}$ and Renata A. N. Pereira ${ }^{2,3}$ \\ ${ }^{1}$ Universidade Federal de Lavras, Lavras, MG 37200-000, Brazil \\ ${ }^{2}$ Better Nature Research Center, ljaci, MG 37218-000, Brazil \\ ${ }^{3}$ Empresa de Pesquisa Agropecuária de Minas Gerais, Lavras, MG 37200-000, Brazil
}

\section{ABSTRACT}

Rehydrated and ensiled mature ground corn has high ruminal starch digestibility, but particle size (PS) and dietary starch proportion (ST) can affect starch digestion and lactating cow performance. We evaluated the effect of rehydrated and ensiled corn (REC), PS, and ST on intake, lactation performance, nutrient digestibility, ruminal fermentation profile, and chewing behavior of dairy cows. Kernels from an $84 \%$ vitreousness hybrid were finely $(\mathrm{FN})$ or coarsely (CS) ground, yielding geometric mean particle sizes of 1,591 and 2,185 $\mu \mathrm{m}$, respectively. Ground kernels were rehydrated $[60 \%$ dry matter (DM)] and ensiled in 200-L buckets for $\geq 205$ d. The grinding rate $(\mathrm{t} / \mathrm{h})$ was 3.9 for $\mathrm{FN}$ and 11.7 for CS. The PS did not affect DM loss (11.3\% of ensiled) or silage $\mathrm{pH}(3.8)$. Samples of each bucket $(\mathrm{n}=15 / \mathrm{PS})$ before and after silage fermentation were incubated in situ for $0,3,6,18$, and $48 \mathrm{~h}$ in 4 rumen-cannulated lactating cows. Ensiling increased the effective ruminal in situ DM degradation (63.7 vs. $34.1 \%$ ), regardless of PS. Sixteen Holstein cows $(152 \pm 96 \mathrm{~d}$ in milk) in $4 \times$ 4 Latin squares (21-d periods) were individually fed a $2 \times 2$ factorial combination of low (LO) or high (HI) starch diets with FN or CS. Cows were fed the same REC incubated in situ. Varied concentration of starch in the diet (29.2 vs. $23.5 \%$ of DM) was achieved by partial replacement of REC (22.0 vs. $14.2 \%$ of DM) with citrus pulp ( 0 vs. $8.2 \%$ of DM). Milk, protein, fat, and lactose yields did not differ. Milk fat percentage was reduced and protein percentage was increased by HI. Treatment FN increased feed efficiency (energycorrected milk/digestible organic matter intake) when fed with HI. Total-tract starch digestibility tended to be reduced by CS (96.4 vs. $97.2 \%$ of starch intake). Serum $\beta$-hydroxybutyrate was increased by LO. High-

Received March 1, 2019

Accepted July 18, 2019.

*Corresponding author: mpereira@ufla.br starch diet reduced the molar proportions of acetate and butyrate in ruminal fluid and increased propionate and isoacids. Particle size did not affect ruminal fermentation profile. Coarse grinding reduced plasma D-lactate concentration with HI. Diet HI reduced the proportion of daily intake from 1900 to $0700 \mathrm{~h}$ and induced preferential intake of feed particles $<8 \mathrm{~mm}$ and greater refusal of particles $>19 \mathrm{~mm}$ in the morning. Fine REC reduced rumination time per day and increased eating time per DM intake. Milk and plasma urea-N did not differ. Ensiling of mature flint corn for $>200 \mathrm{~d}$ largely eliminated the effect of the PS of REC on the studied outcomes. The proportion of REC in the diet affected ruminal fermentation profile and milk solids concentration, but did not affect short-term performance and digestibility. Coarse grinding of REC may allow increasing the grinding rate and thus save labor and energy during ensiling.

Key words: corn grain silage, particle size of corn, reconstituted corn, starch digestibility

\section{INTRODUCTION}

Corn hybrids with a high content of vitreous endosperm have lower ruminal and intestinal starch digestibility than floury endosperm hybrids (Taylor and Allen, 2005), and such hybrids are the predominant form of corn cultivated in Brazil (Correa et al., 2002). Storage of this corn by rehydration and ensiling of ground mature kernels can increase total-tract diet digestibility relative to finely ground mature flint corn (Bitencourt, 2012; Arcari et al., 2016). The degradation of prolamin by microbial and plant proteases during ensiling can increase corn digestibility (Heron et al., 1986; Hoffman et al., 2011; Junges et al., 2017), and the gain in digestible starch seems to be related to the duration of storage (Kung et al., 2018). The increase in starch digestibility can improve lactation performance and feed efficiency of dairy cows (Firkins et al., 2001; Ferraretto et al., 2013). 
Particle size at milling can affect the grinding rate of kernels and the cost per ton of corn processed for storage as rehydrated and ensiled corn (REC; Headley and Pfost, 1968). Particle size of corn can also determine the degree of prolamin degradation in the silo (Baron et al., 1986). Fine grinding $(1,020$ vs. $3,780 \mu \mathrm{m})$ of high-moisture corn (HMC) increased total-tract starch digestibility but had no effect on milk yield, DMI, and ruminal fermentation profile of cows fed $35 \%$ starch in the diet (San Emeterio et al., 2000). Reis et al. (2001) observed that fine grinding of HMC (2,220 vs. 3,140 $\mu \mathrm{m})$ increased milk protein secretion and tended to increase the total-tract starch digestibility but had no effect on ruminal $\mathrm{pH}$ and fermentation profile, DMI, and milk yield of cows fed a direct-cut forage and $39 \%$ starch in the diet.

Variation of the particle size of corn can be used to manipulate the proportion of dietary starch digested in the rumen or intestines (Galyean et al., 1979; Rémond et al., 2004). Knowlton et al. (1998) fed HMC ground or rolled after ensiling (489 vs. 1,789 $\mu \mathrm{m}$ ) to lactating cows with ruminal, duodenal, and ileal cannulas and observed trends for increased ruminal $(+5.6$ percentage units), intestinal $(+9.2$ percentage units), and totaltract $(+2.5$ percentage units) starch digestibilities and milk yield with fine grinding, with no change in ruminal $\mathrm{pH}$ or fermentation profile. Grinding of corn can increase the rate of passage of grain from the rumen as well as the rate of digestion within the rumen (Ewing et al., 1986), both having opposing effects on ruminal starch digestion and fermentation profile.

Increased ruminal starch digestibility can reduce DMI (Allen, 2000), and the effect of starch digestibility on productivity of dairy cows may differ by concentration of starch in the diet. Oba and Allen (2003a) fed cows diets with 21.2 or $31.6 \%$ of starch in DM either by partially replacing $\mathrm{HMC}(1,863 \mu \mathrm{m})$ or mature ground corn $(885 \mu \mathrm{m})$ in the high-starch diet with forages. The HMC reduced DMI with high starch but did not affect DMI with low starch, which was associated with reduced meal size on HMC. The high-starch diet increased solids-corrected milk yield compared with the low-starch diet for cows fed ground corn, but it did not increase solids-corrected yield for cows fed HMC. The difference in ruminal starch digestibility between HMC and ground corn was greater for high compared with low dietary starch concentration.

Therefore, the objective of this study was to evaluate intake, lactation performance, nutrient digestibility, ruminal fermentation profile, and chewing and sorting behaviors of lactating dairy cows fed high (HI) or low $(\mathbf{L O})$ starch diets containing fine $(\mathbf{F N})$ or coarse $(\mathbf{C S})$ particle size (PS) REC. Our hypothesis was that feeding diet $\mathrm{HI}$ with FN would induce ruminal acidosis, thus impairing performance, and feeding LO with CS would result in decreased milk yield.

\section{MATERIALS AND METHODS}

The experimental protocol was approved by the University of Lavras Bioethic Committee in Utilization of Animals.

\section{Rehydrated Corn Grain Silage}

Kernels from a mature corn hybrid (Dow 2B707, Dow AgroSciences Industrial Ltda, São Paulo, Brazil) with a high proportion of vitreous endosperm ( $84 \%$ of endosperm; Correa et al., 2002) were ground with a stationary hammer mill (Nogueira TN-8, Nogueira Máquinas Agrícolas, São João da Boa Vista, São Paulo, Brazil) using either a 3-mm (FN) or a 9-mm (CS) mesh diameter screen. Twenty kernels of various physical forms were randomly selected for vitreous endosperm determination. Briefly, kernels were immersed in distilled water for $3 \mathrm{~min}$ and dried with a paper towel, and the total endosperm was weighed after pericarp and germ removal. The floury endosperm was removed, and the vitreous endosperm was expressed as a percentage of total endosperm. The grinding rate $(\mathrm{t} / \mathrm{h})$ of $30-\mathrm{kg}$ corn samples was measured $(\mathrm{n}=39 / \mathrm{PS})$. Ground corn was mixed with water in a TMR mixer to achieve at least $35 \%$ moisture for ensiling without additives in 200-L buckets. The mean duration of storage was $247 \pm 24 \mathrm{~d}$ (205-289 d).

Fifteen 200-L buckets of each REC were fed to dairy cows during the 84-d experimental period (126 $\pm 4 \mathrm{~kg}$ of corn DM/bucket). A sample from each bucket was obtained daily, and a composite sample was made per bucket and frozen until analysis. The loss of DM during storage was calculated by measuring the DM concentration of the rehydrated corn before and after ensiling. The DM concentration was measured in a forced-air oven set at $55^{\circ} \mathrm{C}$ for $72 \mathrm{~h}$ and subsequent drying at $105^{\circ} \mathrm{C}$ for $24 \mathrm{~h}$. Thawed REC samples $(25 \mathrm{~g})$ were blended with $225 \mathrm{~mL}$ of distilled water, and solution $\mathrm{pH}$ was measured (HI $2210 \mathrm{pH}$ meter, Hanna Instruments, Woonsocket, RI). This solution was diluted (1:1) with distilled water and the concentration of $\mathrm{NH}_{3}-\mathrm{N}$ was evaluated according to Chaney and Marbach (1962). The proportion of $\mathrm{CP}$ as $\mathrm{NH}_{3}-\mathrm{N}$ was determined.

Corn PS was measured for unfermented and fermented samples from each bucket ( $\mathrm{n}=15$ buckets/ PS). Corn samples were dried in a forced-air oven at $55^{\circ} \mathrm{C}$ for $72 \mathrm{~h}$, as described previously, and then drysieved. Samples $(125 \pm 1.4 \mathrm{~g})$ were dry-sieved for 10 min with a Bertel shaker (Bertel Indústria Metalúrgica Ltda., Caieiras, São Paulo, Brazil) with sieves of square 
diagonal apertures of 4,750,2,830, 1,400, 1,000, 600, and $250 \mu \mathrm{m}$ and a pan. The proportion of particles retained on each sieve was determined. The geometrical mean particle size (GMPS, $\mu \mathrm{m})$, particles per gram, and surface area $\left(\mathrm{cm}^{2} / \mathrm{g}\right)$ were calculated as in Baker and Herrman (2002).

The ruminal in situ DM disappearance of unfermented and fermented corn samples from the 15 buckets of REC was evaluated in 4 rumen-cannulated cows in mid lactation $(26.3 \pm 3.6 \mathrm{~kg} / \mathrm{d}$ of milk) fed a TMR based on corn silage, soybean meal, and REC. Corn was dried at $55^{\circ} \mathrm{C}$ for $72 \mathrm{~h}$, and $5.52 \pm 0.04 \mathrm{~g}$ of each unground sample was inserted into $10 \times 20 \mathrm{~cm}$ nonwoven textile bags $\left(100 \mathrm{~g} / \mathrm{m}^{2}\right)$. Incubation times were $0,3,6,18$, and $48 \mathrm{~h}$ (duplicate bags for each time point). Bags were soaked for $30 \mathrm{~s}$ in warm water before incubations. After removal from the rumen, bags were immersed in icy water for $15 \mathrm{~min}$. The $0 \mathrm{~h}$ bags were immersed in water at room temperature for 30 min before washing with the incubated bags in 2 washing machine cycles. A 2-pool model was used to describe corn DM degradation kinetics (Fernandes et al., 2018). The rapidly degradable A fraction (\% of $\mathrm{DM})$ was the $0 \mathrm{~h}$ bag disappearance, and the slowly degradable B fraction was $100-\mathrm{A}$. The fractional degradation rate of $\mathrm{B}\left(\mathbf{k}_{\mathrm{d}}, \% / \mathrm{h}\right)$ was the slope of the linear regression of the natural logarithm of the bag residue as a proportion of the incubated sample size over times 0 to $48 \mathrm{~h}$. The effective ruminal degradation (ERD) was $\mathrm{A}+\mathrm{B} \times\left[\mathrm{k}_{\mathrm{d}} /\left(\mathrm{k}_{\mathrm{d}}+\mathrm{k}_{\mathrm{p}}\right)\right]$, where $\mathrm{k}_{\mathrm{p}}$ is the fractional passage rate of concentrates $(6.5 \% / \mathrm{h})$ estimated with the equation of Seo et al. (2006) for the average experimental cow and diet.

\section{Cows and Treatments}

The lactating cow experiment was conducted from January 1 to April 3, 2016. Cows were individually fed in an open-walled, sand-bedded tie-stall barn with fans and high-pressure sprinklers at the Better Nature Research Center (Ijaci, Minas Gerais, Brazil). Sixteen lactating Holstein cows (152 \pm 96 DIM, 4 primiparous) were grouped in 4 homogeneous squares by parity (1 vs. $>1$ ) and milk yield during $5 \mathrm{~d}$ before blocking. Within a square, cows were randomly allocated to a sequence of 4 treatments in $4 \times 4$ Latin squares balanced for carryover effects, with 21-d periods, and $14 \mathrm{~d}$ of adaptation to treatments. Treatments were a $2 \times 2$ factorial arrangement of dietary starch concentration (LO vs. HI) and REC PS (FN vs. CS) (Table 1).

Feeds were mixed and offered at 0700 and $1300 \mathrm{~h}$ in amounts to allow for 7 to $10 \%$ of offered as daily refusal per cow. Feed was pushed up at least 10 times/d

Table 1. Ingredient and nutrient composition (\% of DM) and particle size distribution (\% of as fed) of the TMR on treatments with high or low starch concentration and fine-ground (FN) or coarse-ground (CS) rehydrated and ensiled corn (REC)

\begin{tabular}{|c|c|c|c|c|}
\hline \multirow[b]{2}{*}{ Item } & \multicolumn{2}{|c|}{ High } & \multicolumn{2}{|c|}{ Low } \\
\hline & FN & $\mathrm{CS}$ & $\mathrm{FN}$ & CS \\
\hline Oat hay & 4.0 & 4.0 & 4.0 & 4.0 \\
\hline Corn silage & 43.4 & 43.3 & 43.2 & 43.1 \\
\hline Whole cottonseeds & 8.6 & 8.6 & 8.6 & 8.6 \\
\hline Soybean meal & 18.7 & 18.7 & 18.6 & 18.6 \\
\hline Fine or coarse REC & 22.0 & 22.2 & 14.2 & 14.4 \\
\hline Citrus pulp pellets & & & 8.2 & 8.1 \\
\hline Magnesium oxide & 0.28 & 0.28 & 0.28 & 0.28 \\
\hline Sodium bicarbonate & 0.88 & 0.88 & 0.87 & 0.87 \\
\hline Salt & 0.19 & 0.18 & 0.18 & 0.18 \\
\hline Limestone & 1.37 & 1.37 & 1.37 & 1.36 \\
\hline Minerals and vitamins ${ }^{1}$ & 0.46 & 0.46 & 0.46 & 0.46 \\
\hline $\mathrm{CP}$ & 17.0 & 17.2 & 17.0 & 17.0 \\
\hline $\mathrm{NDF}$ & 35.1 & 35.0 & 36.1 & 36.1 \\
\hline Forage NDF & 26.2 & 25.7 & 25.6 & 25.6 \\
\hline Ether extract & 5.5 & 5.5 & 5.3 & 5.3 \\
\hline Ash & 7.4 & 7.3 & 7.8 & 7.8 \\
\hline $\mathrm{NFC}^{2}$ & 35.1 & 35.0 & 33.8 & 33.9 \\
\hline Starch & 29.1 & 29.2 & 23.5 & 23.5 \\
\hline \multicolumn{5}{|l|}{ Particle size distribution ${ }^{3}$} \\
\hline Feed particles >19 mm & $10.0 \pm 2.3$ & $9.4 \pm 2.9$ & $11.3 \pm 3.3$ & $10.6 \pm 3.6$ \\
\hline Feed particles 8-19 mm & $40.1 \pm 4.8$ & $40.4 \pm 4.6$ & $41.2 \pm 3.9$ & $41.2 \pm 5.1$ \\
\hline Feed particles $<8 \mathrm{~mm}$ & $49.9 \pm 6.0$ & $50.2 \pm 5.7$ & $47.5 \pm 6.3$ & $48.2 \pm 7.6$ \\
\hline
\end{tabular}


to stimulate intake. Cows were milked 3 times per day at 0500,1300 , and $2000 \mathrm{~h}$ in an adjacent herringbone parlor. Corn silage DM concentration was measured weekly and REC DM concentration was measured daily with a microwave oven, and the TMR was adjusted accordingly.

\section{Sample Collection and Analysis}

Samples of orts per cow and feeds were obtained daily during the third week of each experimental period and frozen, and period composites (equal as-fed amounts of daily samples) were frozen. Period composite samples were dried in forced-air oven at $55^{\circ} \mathrm{C}$ for $72 \mathrm{~h}$ and ground to pass a 1-mm-diameter mesh screen (Wiley mill, Thomas Scientific, Swedesboro, NJ). The DM concentration was determined by drying samples at $100^{\circ} \mathrm{C}$ for $24 \mathrm{~h}$. The CP concentration was determined with a micro Kjeldahl apparatus (AOAC International, 2006; method 990.03), ash by incineration at $550^{\circ} \mathrm{C}$ for $8 \mathrm{~h}$, the ash-free NDF by filtration in porous crucibles with heat-stable $\alpha$-amylase and sodium sulfite (AOAC International, 2006; method 2002-04), and the ether extract as in AOAC International (2006; method 2003.05). The NFC fraction was calculated as follows: $100-(\mathrm{CP}+$ ether extract + ash + NDF). Starch was analyzed enzymatically according to Hall (2009). The ingredient composition of the offered TMR was calculated based on the offered as fed amounts of each feed multiplied by its DM concentration (Table 1). The composition of the consumed diet in nutrients was the nutrient intake of all cows on a treatment (offered minus orts) divided by the entire experiment DMI of the treatment. The PS distribution of the fresh TMR was measured on the weekly composites with the Penn State Particle Separator using the 8- and 19-mm-diameter screens and pan (Lammers et al., 1996).

Milk yield was recorded daily throughout the experiment, and the mean yield of d 15 to 21 was used to compare treatments. On d 18 to 21 , daily milk samples were collected in proportion to the amount produced in each milking. Samples were stored in flasks containing 2-bromo-2-nitropropane-1-3-diol under refrigeration until shipping to the laboratory of the Paraná State Holstein Breeders Association (APCBRH, Curitiba, Paraná, Brazil). Milk solids concentration and MUN were measured by mid-infrared analysis (Bentley Instruments Inc., Chaska, MN). Milk energy secretion (Mcal/d) was calculated according to the following equation (National Research Council, 2001): [(0.0929 $\times$ $\%$ fat $)+(0.0547 \times \%$ protein $)+(0.0395 \times \%$ lactose $)]$ $\times \mathrm{kg}$ of milk. The secretion of ECM $(\mathrm{kg} / \mathrm{d})$ was calculated as milk energy secretion divided by 0.70 (assumes $0.70 \mathrm{Mcal} / \mathrm{kg}$ of milk with $3.7 \%$ fat, $3.2 \%$ protein, and
$4.6 \%$ lactose). The BW and BCS were measured on d 21 of each period. The BW was measured after the morning milking, and BCS (1-5, thin to fat) was the mean of 3 independent evaluators.

Total-tract apparent digestibilities of DM, OM, NDF, and starch were determined by collection of feces on $\mathrm{d}$ 19 to 21 . Feces were collected in buckets by 1 person for every 2 cows concurrent to defecation during three 8-h sampling periods and weighed. The second and third sampling periods were each delayed by $8 \mathrm{~h}$, thus representing a 24-h collection. Fecal aliquots (equal fresh weight basis) were immediately frozen throughout the collection period, and a composite sample was formed per cow. Composite fecal samples were dried for $72 \mathrm{~h}$ at $55^{\circ} \mathrm{C}$ in a forced air oven. Concentrations of DM, NDF, starch, and ash were determined as previously described. The daily digestible OM intake (DOMI) was calculated. Feed efficiencies were calculated as milk yield/DMI, ECM/DMI, and ECM/DOMI.

The urinary output was collected in buckets as cows urinated (1 person/2 cows), simultaneously with fecal sampling, to estimate the relative ruminal microbial yield based on allantoin excretion ( $\mathrm{mmol} / \mathrm{d})$. A $20 \%$ sulfuric acid solution $(200 \mathrm{~mL})$ was placed in $20-\mathrm{L}$ buckets, and urine was added to it during the collection period. At the end of the 3 -d collection period, composite urine samples were diluted 1:5 with $4 \%$ sulfuric acid solution and frozen at $-20^{\circ} \mathrm{C}$. Allantoin was analyzed according to Chen and Gomes (1992). The efficiency of microbial growth was estimated as allantoin/DOMI $(\mathrm{mmol} / \mathrm{kg})$.

Ruminal fluid samples were obtained on d 21 with a flexible oro-gastric tube at $10.5 \pm 0.5 \mathrm{~h}$ after morning feeding. All cows were randomly sampled within squares. Samples were strained through 2 layers of cheesecloth. A sample was frozen in liquid nitrogen to suppress fermentation and stored at $-20^{\circ} \mathrm{C}$ until preparation for analysis of VFA by HPLC (LC-10Ai, Shimadzu Corp., Tokyo, Japan). An ion exclusion column from Shimadzu (Shim-pack SCR-101H; $7.9 \mathrm{~mm}$ i.d., 30 $\mathrm{cm}$ long) operated at $50^{\circ} \mathrm{C}$ was used. The mobile phase consisted of $100 \mathrm{mM}$ perchloric acid solution at a flow rate of $0.6 \mathrm{~mL} / \mathrm{min}$. The organic acids were detected by UV absorbance. Another ruminal fluid sample was mixed to a $36 \%$ formaldehyde solution for protozoa counting. The sample was stained according to Dehority (1984) and total protozoa was enumerated with an optical microscope in a Neubauer chamber (Warner, 1962).

During d 15, 16, and 17, eating and rumination behaviors were monitored by visual observation of the buccal activities of each cow at 5-min intervals continuously for $24 \mathrm{~h}$. The buccal activities evaluated included eating, water ingestion, rumination, and idleness. Eating 
and rumination per unit of DMI were calculated using the intake on the days on which chewing activity was evaluated. A meal was defined by at least 2 consecutive 5-min eating events following at least $10 \mathrm{~min}$ of idleness or rumination. To generate the meal pattern data, the minimum 10-min intermeal interval was adopted based on the reasoning of Mullins et al. (2012) for a 12-min interval. Meal duration was the ratio between eating time $(\mathrm{min} / \mathrm{d})$ and meals per day. The duration of the first daily meal (conditioned meal) was measured with a chronometer. Five evaluators observed the behavior of all cows after feed was offered at $0700 \mathrm{~h}$ until the last cow finished its first meal.

On $\mathrm{d} 16$, the proportions of daily intake in the morning (0700-1300 h), afternoon (1300-1900 h), and night $(1900-0700 \mathrm{~h})$ were determined by measuring feed availability per cow at 0700,1300 , and $1900 \mathrm{~h}$ and orts at 1300, 1900, and $0700 \mathrm{~h}$. Particle size sorting behavior was evaluated by the proportion of particles above the 19-mm mesh diameter screen and above and below the 8-mm mesh screen of the Penn State Particle Separator (Lammers et al., 1996) at 0700 and $1300 \mathrm{~h}$ for the offered TMR and at 1300, 1900, and $0700 \mathrm{~h}$ for refusals. Feed refusals at $1300 \mathrm{~h}$ were mixed with feed offered at $1300 \mathrm{~h}$ for measurement of the offered TMR particle size of each cow. The predicted intake (as-fed basis) of particles on each screen was calculated as \% TMR retained on screen $\times \mathrm{kg}$ of TMR consumed. The observed intake of particles was $\%$ TMR retained on screen $\times \mathrm{kg}$ of TMR offered $-\%$ orts retained on screen $\times \mathrm{kg}$ of orts. For the calculation of starch and NDF sorting behaviors, the predicted intake of a nutrient was $\%$ of nutrient in offered TMR DM $\times \mathrm{kg}$ of DMI. The observed intake was \% of nutrient in offered TMR DM $\times \mathrm{kg}$ of offered TMR DM $-\%$ of nutrient in orts $\mathrm{DM} \times \mathrm{kg}$ of orts DM. The selection index was: $100 \times$ (observed intake/predicted intake). Sorting values below $100 \%$ represent selective refusal, above $100 \%$ represent preferential intake, and equal to $100 \%$ represent no selection.

On d 18, plasma urea-N (PUN) was measured for samples obtained from the coccygeal vessels at 0,1 , $3,6,9,15$, and $21 \mathrm{~h}$ after morning feeding. After collection in vacutainer tubes with EDTA, blood was centrifuged at $2,000 \times g$, and the plasma was frozen at $-20^{\circ} \mathrm{C}$. The analysis was performed using a commercial kit (Urea Enzimática, Bioclin, Belo Horizonte, Minas Gerais, Brazil). Blood was also collected $12 \mathrm{~h}$ post-feeding in tubes containing potassium fluoride to analyze the concentrations of glucose (Glicose Enzimática Líquida, Doles Reagentes para Laboratórios Ltda, Goiânia, Goiás, Brazil) and D-lactate (D-Lactate Colorimetric Assay Kit, MAK058, Sigma-Aldrich, St. Louis, MO). Serum BHB concentration was determined
$12 \mathrm{~h}$ post-feeding (FreeStyle Optium $\beta$-Ketone, Witney, UK). Jugular blood $\mathrm{pH}$ and gases were analyzed $6 \mathrm{~h}$ post-feeding with an AGS 22 blood gas analyzer (Drake Eletrônica e Comércio Ltda, São José do Rio Preto, São Paulo, Brazil). Samples were obtained in heparinized tubes and analyzed less than $1 \mathrm{~h}$ after sampling. The duration of the entire sampling procedure was less than 30 min, sampling was performed at random within squares, and samples were kept under refrigeration until analysis.

\section{Statistical Analysis}

Data were analyzed with the MIXED procedure of SAS (SAS Institute, Cary, NC). Silage variables were analyzed as a completely randomized design. Particle size and ruminal degradation kinetics of FN and CS were analyzed with a model considering unfermented and fermented samples as repeated measures of the same bucket of REC ( $\mathrm{n}=15 / \mathrm{PS})$. The model contained the fixed effects of PS and ensiling and the interaction between PS and ensiling. Bucket nested within PS was the whole plot error.

The Latin square model had the fixed effects of period (1-4), ST (HI, LO), and PS (FN, CS), and the interaction between ST and PS. Cow (1-16) was random in the model. The Kenward-Roger method was used to calculate degrees of freedom. For data obtained over time (PUN), the fixed effect of time $(0,1,3,6,9,15,21$ $\mathrm{h}$ ) and the 2- and 3-term interactions between time, S, and PS were added to the previous model. The wholeplot error was the interaction between cow, period, S, and PS. First-order autoregressive covariance structure was used based on the lowest Akaike information criterion value. Statistical significance was declared at $P \leq$ 0.05 and trends at $P \leq 0.10$. The Bonferroni test was performed to detect differences among treatments after having a $P \leq 0.10$ for the interaction between ST and PS.

\section{RESULTS}

The composition of the consumed TMR is shown in Table 1. Dietary starch proportion was $29.1 \%$ of DM for $\mathrm{HI}$ and $23.5 \%$ of DM for LO. The proportion of REC was 22.1 and $14.3 \%$ of DM in diets HI and LO, respectively. The nutrient composition of FN and CS was similar (Table 2). Silage DM concentration was $60 \%$ of as fed $(P=0.26)$, and $\mathrm{pH}$ was $3.8(P=0.21)$ (Table 3$)$. Silage PS did not affect the loss of DM during storage (11.3\% of ensiled, $P=0.33$ ) or the proportion of $\mathrm{N}$ as $\mathrm{NH}_{3}-\mathrm{N}(4.7 \%, P=0.16)$. Grinding rates were $3.9 \pm 0.2$ $\mathrm{t} / \mathrm{h}$ for $\mathrm{FN}$ and $11.7 \pm 0.5 \mathrm{t} / \mathrm{h}$ for CS $(\mathrm{n}=39 / \mathrm{PS})$. 
Table 2. Composition of feed ingredients (\% of DM); mean \pm SD of composite samples per period $(\mathrm{n}=4)$

\begin{tabular}{|c|c|c|c|c|c|c|}
\hline Ingredient & $\mathrm{CP}$ & NDF & Ether extract & Ash & $\mathrm{NFC}^{1}$ & Starch \\
\hline Corn silage & $7.7 \pm 0.2$ & $48.3 \pm 1.7$ & $4.0 \pm 0.4$ & $4.4 \pm 0.3$ & $32.8 \pm 3.2$ & $25.0 \pm 3.4$ \\
\hline Whole cottonseed & $21.6 \pm 0.2$ & $50.4 \pm 0.2$ & $20.5 \pm 0.5$ & $4.2 \pm 0.1$ & $3.5 \pm 0.2$ & $8.5 \pm 0.4$ \\
\hline $\mathrm{REC}^{2}$ fine & $9.1 \pm 0.1$ & $9.6 \pm 0.2$ & $6.1 \pm 0.3$ & $1.3 \pm 0.1$ & $74.5 \pm 0.6$ & $72.3 \pm 1.7$ \\
\hline REC coarse & $9.0 \pm 0.1$ & $9.5 \pm 0.4$ & $6.1 \pm 0.2$ & $1.5 \pm 0.2$ & $74.7 \pm 0.8$ & $72.1 \pm 1.8$ \\
\hline Citrus pulp & $7.3 \pm 0.2$ & $23.7 \pm 0.5$ & $2.9 \pm 0.1$ & $7.3 \pm 0.2$ & $59.0 \pm 0.6$ & $4.5 \pm 0.4$ \\
\hline
\end{tabular}

${ }^{1} \mathrm{NFC}=100-(\mathrm{CP}+\mathrm{NDF}+$ ether extract $+\mathrm{ash})$.

${ }^{2}$ Rehydrated and ensiled corn.

The PS and ruminal degradation kinetics of unfermented and fermented corn are presented in Table 4 . Fine grinding reduced GMPS from 2,185 to 1,589 $\mu \mathrm{m}$ and increased particles per gram and surface area $(P$ $<0.01)$. Ensiling increased surface area and particles per gram $(P \leq 0.02)$ but had no effect on GMPS $(P=$ 0.94). At similar GMPS, ensiling affected the proportion of particles in 6 of the 7 PS ranges evaluated ( $P$ $\leq 0.04)$. A trend was detected for the interaction of ensiling and PS $(P=0.10)$, and the Bonferroni test $(P \leq 0.05)$ suggested that the number of particles per gram was increased more by fine grinding on fermented corn than on unfermented. Significant interactions between ensiling and PS were detected for the proportion of particles retained on the 1,400- and 1,000- $\mu \mathrm{m}$ mesh screens $(P<0.01)$. Fine grinding increased the proportion of particles on both screens, but the magnitude of the effect on unfermented corn differed from that on fermented corn.

The degree of grinding did not determine the size of fraction A, estimated by the $0 \mathrm{~h}$ degradation $(P=0.36)$. Ensiling increased fraction A from 12.5 to $52.0 \%$ of DM $(P<0.01)$. Interactions between ensiling and PS were detected for the 3-, 6-, 18-, and 48-h ruminal degradations $(P \leq 0.03)$. Fine grinding increased the ruminal DM degradability of unfermented corn at the various incubation times, but PS did not affect the degradability of fermented corn. Ensiling tended to reduce the $\mathrm{k}_{\mathrm{d}}$ of fraction B (2.03 vs. $2.15 \% / \mathrm{h}, P=0.08)$, but PS did not affect the $\mathrm{k}_{\mathrm{d}}(P=0.17)$. The estimated ERD was $34.2 \%$ of DM for unfermented corn and $63.8 \%$ of DM for fermented corn $(P<0.01)$.
Intake, lactation performance, and feed efficiencies are shown in Table 5. No effects of ST $(P \geq 0.39)$ or PS $(P \geq 0.38)$ were found for the yields of milk and ECM. A high proportion of REC in the diet reduced milk fat percentage (3.22 vs. $3.34 \%, P=0.04)$, increased protein percentage (3.20 vs. $3.13 \%, P=0.03)$, and tended to reduce lactose percentage (4.42 vs. $4.46 \%, P=0.06)$, but yields of fat, protein, and lactose did not differ $(P \geq 0.19)$. Particle size of REC had no effect on the concentrations and yields of fat, protein, or lactose in milk $(P \geq 0.34)$. Trends were observed for the interactions between ST and PS for DMI and DOMI $(P=$ 0.08). Cows fed FN with HI tended to have lower DMI than FN with LO $(P \leq 0.10$ for Bonferroni), but DMI of the CS diets did not differ. Diet FN with HI tended to reduce DOMI relative to CS with $\mathrm{HI}(P \leq 0.10$ for Bonferroni), but PS of REC did not affect DOMI with diet LO. A trend for an interaction between ST and PS was detected for ECM/DMI $(P \leq 0.10)$ and an interaction was detected for ECM/DOMI $(P \leq 0.04)$. Diet FN with HI tended to increase ECM/DMI $(P \leq 0.10$ for Bonferroni) and increased ECM/DOMI $(P \leq 0.05$ for Bonferroni) compared with CS with HI, but PS did not affect feed efficiencies with LO.

Table 6 reports the total-tract apparent digestibility of nutrients, the relative ruminal microbial yield estimated by the daily urinary allantoin excretion, and plasma glucose and serum BHB concentrations. The total-tract starch digestibility tended to be increased by $\mathrm{FN}$ relative to CS (97.2 vs. $96.3 \%, P=0.06)$, and ST did not affect starch digestibility $(P=0.25)$. The daily excretion of urinary allantoin was not affected by

Table 3. Silage DM loss, $\mathrm{pH}, \mathrm{DM}, \mathrm{CP}$, and $\mathrm{NH}_{3}-\mathrm{N}$ concentrations of fine-ground (FN) or coarse-ground (CS) rehydrated and ensiled corn; $\mathrm{n}=15$ buckets $(200 \mathrm{~L})$

\begin{tabular}{lrrrc}
\hline Item & FN & CS & SEM & $P$-value \\
\hline Nonvolatile DM loss, \% of ensiled & 11.1 & 11.5 & 0.91 & 0.33 \\
$\mathrm{pH}$ & 3.7 & 3.8 & 0.03 & 0.21 \\
$\mathrm{DM}, \%$ of as fed & 59.7 & 60.3 & 0.36 & 0.26 \\
$\mathrm{CP}, \%$ of DM & 8.8 & 8.4 & 0.27 & 0.37 \\
$\mathrm{NH}_{3}$-N, \% of N & 4.4 & 5.0 & 0.31 & 0.16 \\
\hline
\end{tabular}


Table 4. Particle size distribution, geometric mean particle size (GMPS), particles per gram, surface area, ruminal in situ DM degradation (Deg) on incubations for 0 to $48 \mathrm{~h}$, effective ruminal degradation (ERD), and the fractional degradation rate, $\mathrm{k}_{\mathrm{d}}$, of the slowly degradable fraction $\mathrm{B}$ of fine-ground (FN) or coarse-ground (CS) corn unfermented and fermented; $\mathrm{n}=15$

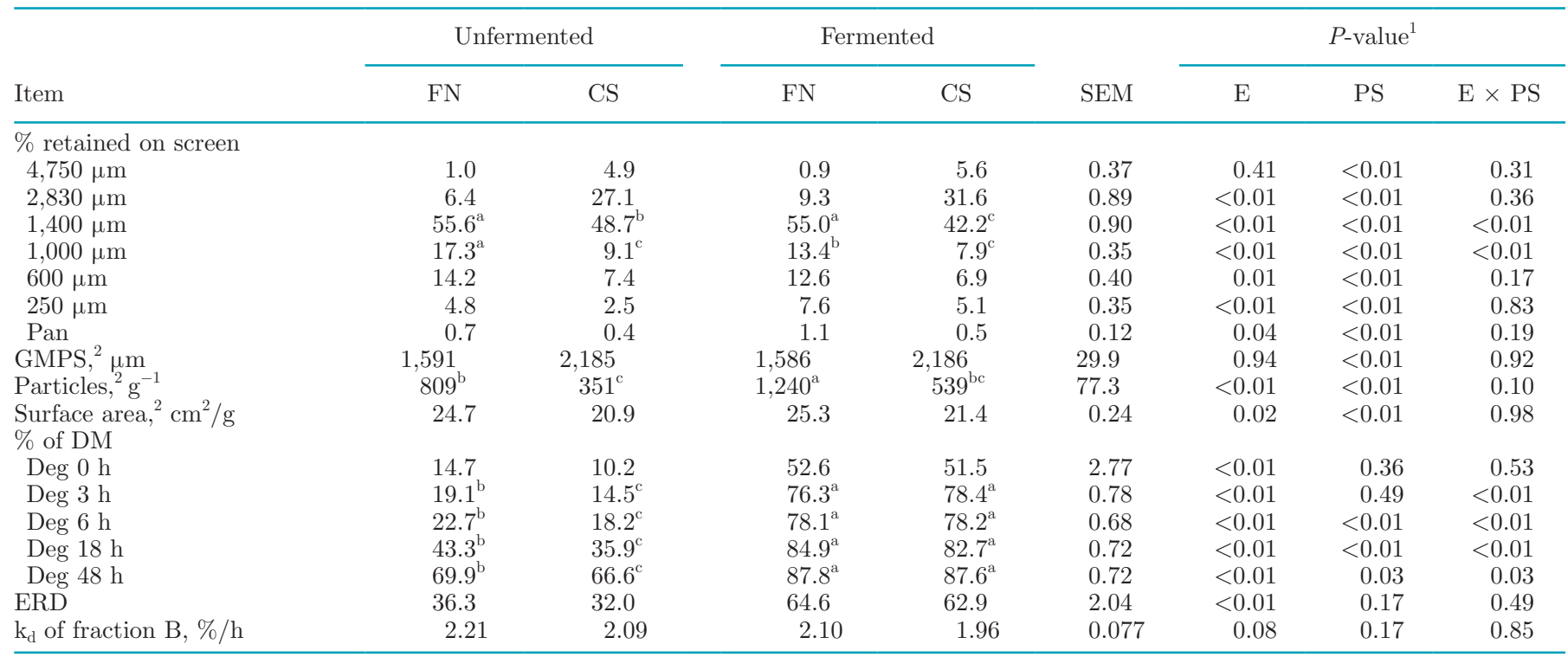

${ }^{a-c}$ Means in a row with differing superscripts differ at $P<0.05$ by the Bonferroni's test.

${ }^{1} \mathrm{E}=$ ensiling; $\mathrm{PS}=$ particle size; $\mathrm{E} \times \mathrm{PS}=$ interaction between $\mathrm{E}$ and $\mathrm{PS}$.

${ }^{2}$ Kansas State University: MF-2051. Baker and Herrman (2002).

ST $(P=0.12)$ and tended to be increased by CS $(244$ vs. $269 \mathrm{mmol} / \mathrm{d}, P=0.09)$, but allantoin excretion per kilogram of DOMI did not differ $(P \geq 0.27)$. Plasma glucose concentration was not responsive to treatments $(P \geq 0.24)$, and LO increased serum BHB $(P=0.01)$.
Ruminal fermentation profile and PUN are shown in Table 6. High starch reduced the molar proportions of acetate and butyrate and the acetate to propionate ratio, and increased the molar proportions of propionate and isoacids relative to LO $(P<0.01)$. Particle size of

Table 5. Intake, lactation performance, MUN, feed efficiencies, BW, and BCS on treatments with high or low starch concentration and fineground (FN) or coarse-ground (CS) rehydrated and ensiled corn

\begin{tabular}{|c|c|c|c|c|c|c|c|c|}
\hline \multirow[b]{2}{*}{ Item } & \multicolumn{2}{|c|}{ High } & \multicolumn{2}{|c|}{ Low } & \multirow[b]{2}{*}{ SEM } & \multicolumn{3}{|c|}{$P$-value ${ }^{1}$} \\
\hline & $\mathrm{FN}$ & $\mathrm{CS}$ & $\mathrm{FN}$ & $\mathrm{CS}$ & & $\mathrm{ST}$ & PS & $\mathrm{ST} \times \mathrm{PS}$ \\
\hline DMI, $\mathrm{kg} / \mathrm{d}$ & $20.2^{\mathrm{B}}$ & $20.7^{\mathrm{AB}}$ & $21.0^{\mathrm{A}}$ & $20.7^{\mathrm{AB}}$ & 0.51 & 0.12 & 0.74 & 0.08 \\
\hline DOMI, ${ }^{2} \mathrm{~kg} / \mathrm{d}$ & $12.6^{\mathrm{B}}$ & $13.8^{\mathrm{A}}$ & $13.6^{\mathrm{AB}}$ & $13.3^{\mathrm{AB}}$ & 0.46 & 0.50 & 0.23 & 0.08 \\
\hline Milk, kg/d & 31.1 & 30.9 & 31.3 & 30.7 & 1.24 & 0.93 & 0.38 & 0.63 \\
\hline ECM, kg/d & 28.7 & 28.3 & 29.0 & 28.8 & 0.93 & 0.39 & 0.50 & 0.85 \\
\hline Fat, kg/d & 0.991 & 0.980 & 1.008 & 1.023 & 0.0369 & 0.19 & 0.91 & 0.57 \\
\hline Protein, kg/d & 0.976 & 0.966 & 0.962 & 0.941 & 0.0248 & 0.31 & 0.44 & 0.76 \\
\hline Lactose, $\mathrm{kg} / \mathrm{d}$ & 1.372 & 1.383 & 1.386 & 1.368 & 0.0587 & 0.98 & 0.92 & 0.63 \\
\hline Solids, kg/d & 3.640 & 3.637 & 3.659 & 3.631 & 0.1288 & 0.92 & 0.83 & 0.86 \\
\hline Fat, $\%$ & 3.22 & 3.21 & 3.28 & 3.39 & 0.095 & 0.04 & 0.34 & 0.30 \\
\hline Protein, \% & 3.20 & 3.20 & 3.13 & 3.13 & 0.106 & 0.03 & 0.90 & 0.99 \\
\hline Lactose, \% & 4.42 & 4.42 & 4.46 & 4.45 & 0.044 & 0.06 & 0.87 & 0.80 \\
\hline Solids, \% & 11.81 & 11.81 & 11.84 & 11.94 & 0.185 & 0.20 & 0.38 & 0.42 \\
\hline MUN, mg/dL & 18.4 & 18.3 & 18.3 & 17.5 & 0.62 & 0.26 & 0.24 & 0.39 \\
\hline Milk/DMI & 1.53 & 1.47 & 1.47 & 1.45 & 0.059 & 0.09 & 0.10 & 0.15 \\
\hline ECM/DMI & $1.43^{\mathrm{A}}$ & $1.37^{\mathrm{B}}$ & $1.38^{\mathrm{B}}$ & $1.39^{\mathrm{B}}$ & 0.038 & 0.57 & 0.28 & 0.10 \\
\hline ECM/DOMI & $2.39^{\mathrm{a}}$ & $2.08^{\mathrm{b}}$ & $2.17^{\mathrm{ab}}$ & $2.17^{\mathrm{ab}}$ & 0.063 & 0.37 & 0.04 & 0.04 \\
\hline $\mathrm{BW}, \mathrm{kg}$ & 607 & 599 & 605 & 597 & 15.9 & 0.52 & 0.21 & 0.99 \\
\hline BCS, 1-5 & 2.99 & 3.00 & 2.96 & 2.95 & 0.057 & 0.29 & 0.96 & 0.79 \\
\hline
\end{tabular}

\footnotetext{
$\overline{\mathrm{A}, \mathrm{B}}$ Means in a row with differing superscripts differ at $P \leq 0.10$ by the Bonferroni's test.

${ }^{\mathrm{a}, \mathrm{b}}$ Means in a row with differing superscripts differ at $P \leq 0.05$ by the Bonferroni's test.

${ }^{1} \mathrm{ST}=$ starch PS $=$ particle size; $\mathrm{ST} \times \mathrm{PS}=$ interaction between $\mathrm{ST}$ and PS.

${ }^{2}$ Digestible OM intake.
} 
Table 6. Total-tract apparent digestibility (D) of DM, OM, NDF, and starch; urinary allantoin (Allant); Allant over digestible OM intake (DOMI); plasma glucose; serum BHB; molar VFA proportions and protozoa in ruminal fluid; and plasma D-lactate and urea-N (PUN) on treatments with high or low starch concentration and fine-ground (FN) or coarse-ground (CS) rehydrated and ensiled corn

\begin{tabular}{|c|c|c|c|c|c|c|c|c|}
\hline Item & \multicolumn{2}{|c|}{ High } & \multicolumn{2}{|c|}{ Low } & SEM & \multicolumn{3}{|c|}{$P$-value ${ }^{1}$} \\
\hline \multicolumn{9}{|l|}{$\%$ of intake } \\
\hline OMD & 66.4 & 70.3 & 69.1 & 68.8 & 1.34 & 0.62 & 0.17 & 0.12 \\
\hline NDFD & 50.1 & 55.2 & 54.4 & 54.8 & 2.21 & 0.39 & 0.22 & 0.15 \\
\hline StarchD & 97.7 & 96.4 & 96.7 & 96.3 & 0.43 & 0.25 & 0.06 & 0.32 \\
\hline Allant/DOMI, $\mathrm{mmol} / \mathrm{kg}$ & 189 & 19.3 & 19.3 & 21.4 & 1.17 & 0.27 & 0.27 & 0.42 \\
\hline Glucose, mg/dL & 69.8 & 73.1 & 67.4 & 69.1 & 2.62 & 0.24 & 0.35 & 0.77 \\
\hline $\mathrm{BHB}, \mathrm{m} M$ & 0.77 & 0.81 & 0.96 & 1.03 & 0.079 & 0.01 & 0.42 & 0.88 \\
\hline \multicolumn{9}{|l|}{$\%$ of VFA } \\
\hline Acetate & 60.6 & 60.5 & 62.8 & 63.0 & 0.74 & $<0.01$ & 0.91 & 0.82 \\
\hline Propionate & 24.3 & 24.1 & 22.0 & 20.6 & 0.77 & $<0.01$ & 0.17 & 0.35 \\
\hline Butyrate & $10.0^{\mathrm{b}}$ & $9.9^{\mathrm{b}}$ & $10.6^{\mathrm{b}}$ & $11.6^{\mathrm{a}}$ & 0.32 & $<0.01$ & 0.15 & 0.10 \\
\hline D-Lactate, $\mu M$ & $81.1^{\mathrm{a}}$ & $60.1^{\mathrm{b}}$ & $73.8^{\mathrm{ab}}$ & $76.2^{\mathrm{ab}}$ & 6.91 & 0.50 & 0.17 & 0.08 \\
\hline $\mathrm{PUN}^{2} \mathrm{mg} / \mathrm{dL}$ & 17.3 & 18.1 & 17.1 & 17.5 & 0.69 & 0.44 & 0.32 & 0.67 \\
\hline
\end{tabular}

${ }^{\mathrm{a}, \mathrm{b}}$ Means in a row with differing superscripts differ at $P \leq 0.05$ by the Bonferroni's test.

${ }^{1} \mathrm{ST}=$ starch; PS $=$ particle size; $\mathrm{ST} \times \mathrm{PS}=$ interaction between $\mathrm{ST}$ and $\mathrm{PS}$.

${ }^{2}$ Samples obtained at $0,1,3,6,9,15$, and $21 \mathrm{~h}$ after morning feeding. $P<0.01$ for hour post-feeding, $P=0.92$ for ST $\times$ hour, $P=0.96$ for PS $\times$ hour, and $P=0.88$ for $\mathrm{ST} \times \mathrm{PS} \times$ hour.

REC had no effect on ruminal fermentation profile $(P$ $\geq 0.17$ ), except for a trend for the interaction between PS and ST for butyrate $(P=0.10)$. The proportion of butyrate in VFA was increased for CS with LO relative to the other 3 diets $(P \leq 0.05$ for Bonferroni). A trend for an interaction between ST and PS was detected for plasma D-lactate $(P=0.08)$. Diet FN with HI induced higher plasma D-lactate than CS with $\mathrm{HI}(P \leq 0.05$ for Bonferroni), but PS of REC had no effect on Dlactate with LO. The concentration of total protozoa in ruminal fluid was similar in all treatments $(P \geq 0.42)$. Blood $\mathrm{pH}$ and gases (Table 7$)$ did not differ $(P \geq 0.21)$, suggesting that treatments did not determine the degree of systemic acidosis. No evidence was found for an effect of ST and PS on PUN $(P \geq 0.24)$ and MUN $(P \geq 0.24$. Table 5). Plasma urea-N peaked at 1 to $3 \mathrm{~h}$ after morning feeding and was lowest in the afternoon (Appendix Figure A1).

Chewing behavior is reported in Table 8. Fine grinding of REC reduced rumination time (466 vs. 486

Table 7. Jugular blood acid-base balance $6 \mathrm{~h}$ post-feeding on treatments with high or low starch concentration and fine-ground (FN) or coarseground (CS) rehydrated and ensiled corn

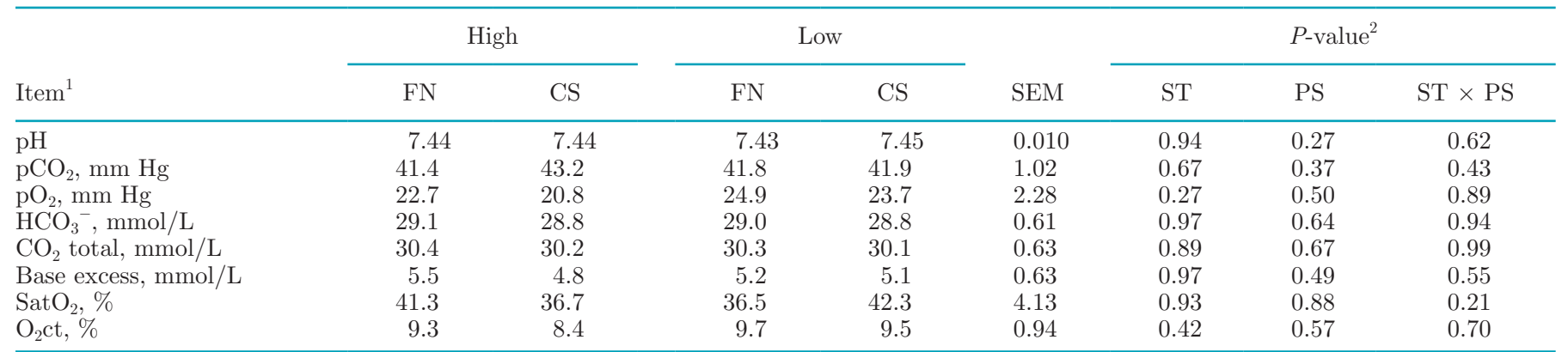

${ }^{1} \mathrm{pCO}_{2}=$ partial pressure of $\mathrm{CO}_{2} ; \mathrm{pO}_{2}=$ partial pressure of $\mathrm{O}_{2}$; SatO $\mathrm{O}_{2}=$ oxygen saturation of hemoglobin; $\mathrm{O}_{2}$ ct $=$ oxygen of the total volume. ${ }^{2} \mathrm{ST}=$ starch; PS $=$ particle size; $\mathrm{ST} \times \mathrm{PS}=$ interaction between $\mathrm{ST}$ and PS. 
$\min / \mathrm{d}, P=0.05)$ and eating time/DMI (16.2 vs. 17.4 $\min / \mathrm{kg}, P=0.04)$. Meal frequency, size, and duration were not affected by treatments $(P \geq 0.16)$. Cows on $\mathrm{HI}$ compared with LO consumed a smaller proportion of the daily intake at night $(P=0.02)$ and tended to consume a larger proportion of the daily intake in the afternoon $(P=0.10)$. Coarse grinding of REC tended to increase the proportion of intake between 1300 and $1900 \mathrm{~h}(P=0.10)$. A trend for an interaction between ST and PS was observed for the proportion of daily intake in the morning $(P=0.06)$. High starch with CS increased the proportion of daily intake in the morning relative to LO with $\mathrm{CS}$ ( $P \leq 0.05$ for Bonferroni), but ST did not affect the proportion of morning intake with FN.

Starch, NDF, and PS sorting behaviors are presented in Table 8. Orts as a proportion of the offered daily TMR was $7.2 \%(P \geq 0.51)$. Fine REC reduced the refusal of NDF compared with $\mathrm{CS}$ (98 vs. $96 \%, P=$ $0.03)$, but it had no effect on starch sorting behavior $(P$ $=0.56)$. Fine grinding also tended to increase the preferential intake of short particles in the morning $(P=$ $0.06)$. The proportion of REC in the diet did not affect starch and NDF sorting behaviors $(P \geq 0.53)$. In the morning, diet HI increased the refusal of long feed particles ( 65 vs. $79 \%, P=0.01$ ) and the preferential intake of short particles (107 vs. $103 \%, P=0.05)$. High-starch diets also increased the selective behavior in favor of intermediate particles at night $(P=0.05)$. An interaction between ST and PS tended to be detected for sorting of short particles at night $(P=0.07)$. For this variable, the effect of PS on sorting behavior occurred with HI and did not occur with LO. Diet FN with HI increased the refusal of long particles at night relative to CS with HI $(P \leq 0.05$ for Bonferroni), but PS did not affect long and intermediate particles sorting behavior with LO.

Table 8. Chewing behavior, proportion of intake in periods of the day, and selectivity on treatments with high or low starch concentration and fine-ground (FN) or coarse-ground (CS) rehydrated and ensiled corn

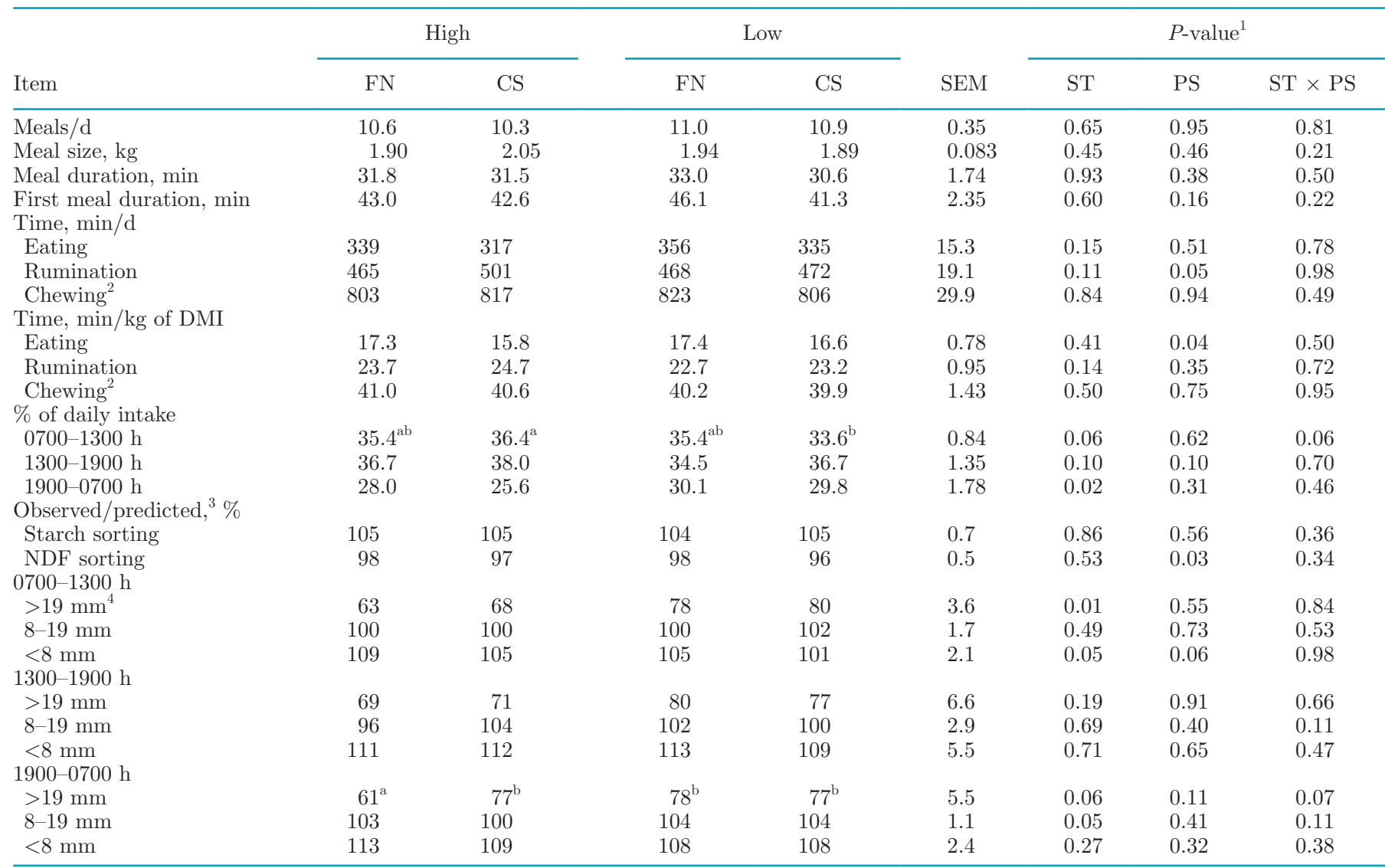

${ }^{\mathrm{a}, \mathrm{b}}$ Means in a row with differing superscripts differ at $P \leq 0.05$ by the Bonferroni's test.

${ }^{1} \mathrm{ST}=$ starch PS $=$ particle size; $\mathrm{ST} \times \mathrm{PS}=$ interaction between $\mathrm{ST}$ and PS.

${ }^{2}$ Chewing $=$ eating + rumination.

${ }^{3}>100=$ preferential intake $; 100=$ refusal; $100=$ no sorting.

${ }^{4}$ Screens of the Penn State Particle Separator. 


\section{DISCUSSION}

The increase in grinding rate from $3.9 \mathrm{t} / \mathrm{h}$ with $\mathrm{FN}$ to $11.7 \mathrm{t} / \mathrm{h}$ with CS is large in magnitude. Faster grinding is operationally desirable at most farms from a labor and energy demand standpoint, but it also increases the necessity of water flow rate for homogeneous hydration of ground corn for storage as REC. The FN and CS silages had moisture concentrations around 40\% and similar $\mathrm{pH}$ (3.7), DM loss during ensiling (11.3\% of ensiled), and nutrient composition. The DM loss and $\mathrm{pH}$ of whole corn were larger than rolled corn stored as HMC and REC (Goodrich et al., 1975). The similarity in DM loss within the range of PS evaluated suggests that PS was not a factor in the storage of corn as REC.

The degree of grinding did not affect the in situ degradation of fermented corn, but unfermented CS corn was less degraded in the rumen than FN. Rehydration to $40 \%$ moisture and ensiling of flint corn for more than $200 \mathrm{~d}$ eliminated the impact of PS on the ruminal degradation of corn grain DM. Similarity in the proportion of $\mathrm{CP}$ as $\mathrm{NH}_{3}-\mathrm{N}$ (Hoffman et al., 2011) suggests that coarse grinding did not reduce prolamin degradation during storage in the silo. Ensiling increased fraction A, the ruminal degradation of DM at all incubation times, and ERD, compared with unfermented corn. The $\mathrm{k}_{\mathrm{d}}$ of fraction $\mathrm{B}$ tended to be reduced by ensiling, with the regression line describing the ln of bag residues over time becoming flatter with increased fraction A. The difference in ERD estimates of unfermented and fermented corn (34.2 vs. $63.8 \%$ of DM) seems to make sense biologically. Ruminal starch digestibility ranged from a mean value of $44.6 \%$ of intake for diets based on dry corn cracked or rolled to $86.8 \%$ of intake for HMC diets in the meta-analysis of Firkins et al. (2001).

Although PS had no effect on ruminal in situ DM degradation of fermented corn, the in vivo total-tract starch digestibility tended to be reduced by 0.9 percentage units by CS. The fecal collection procedure for 3 continuous 8 -h periods during 3 consecutive days to represent the $24 \mathrm{~h}$ of the day has been previously described (Salvati et al.; 2015; Dias et al., 2018), although it has not been validated against total collection of feces for continuous $24 \mathrm{~h}$ for $3 \mathrm{~d}$. A linear regression between fecal starch concentration (\% of DM) and total-tract starch digestibility (\% of starch intake) was generated with 633 lactating cow/observations from 15 experiments conducted in our laboratory and adopting the same fecal collection procedure as in this experiment (M.N. Pereira, unpublished data). The total-tract starch digestibility coefficient of flint corn based diets ranged from 86 to $99 \%$ of starch intake and the linear regression was as follows: total-tract starch digestibility $=100.5-0.9998 \times$ fecal starch concentration $\left(\mathrm{r}^{2}=\right.$
$0.96, P<0.01)$. This regression had a lower slope $(1.0$ vs. 1.2) but a similar intercept (100\%) compared with the regression of Fredin et al. (2014), which was generated mostly with floury hybrids and various indirect methods of estimating fecal excretion. Our fecal collection procedure to estimate total-tract nutrient digestibility seems to have accuracy.

Oba and Allen (2003b) observed that the difference in ruminal starch digestibility between HMC and ground corn in high- and low-starch diets were 24.2 and 12.6 percentage units, respectively, but the change in total-tract starch digestibility was 1.6 and 0.3 percentage units. The compensatory action of the intestines on starch digestibility reduces the difference in ruminal digestibility between diets varying in corn processing and content. Minor changes in total-tract starch digestibility may occur between diets with a large difference in the site of starch digestion in the digestive tract (Nozière et al., 2014; Fredin et al., 2015).

Diet FN with HI increased plasma D-lactate concentration relative to CS with HI, suggestive of a greater degree of ruminal acidosis when REC was finely ground. Diet FN with HI also tended to reduce DOMI and induced short-term increase in feed efficiency (ECM/ DOMI), with a similar yield of ECM. These findings suggest that FN was more rapidly degraded in the rumen than CS. The PS of REC had no effect on lactation performance, intake, and feed efficiency with LO. Oba and Allen (2003a) observed that solids-corrected milk was increased when dietary starch concentration was increased with ground corn, but it did not change when starch was increased with HMC. Increased ruminal starch digestibility may not be advantageous in diets with high starch concentration. Varying the proportion of REC in the diet affected the concentrations of fat and protein in milk, but coarse grinding of REC did not affect milk solids concentration, regardless of dietary starch content.

More starch in the diet increased the molar proportion of propionate and reduced acetate in ruminal fluid, as expected (Ferraretto et al., 2013). The change in fermentation profile was not associated with changes in allantoin excretion in urine, ruminal protozoa concentration, and urea- $\mathrm{N}$ in milk and plasma, suggesting that ruminal starch availability did not affect ruminal microbial synthesis and ammonia loss. Particle size of REC had no effect on ruminal fermentation profile, supporting the minor effect of PS on the ruminal degradation of fermented corn. The increase in butyrate proportion for CS with LO probably reflected an increased contribution of citrus pulp fermentation products to the ruminal VFA pool. The ruminal fermentation of pectin and sugars generates an increased proportion of butyrate in ruminal VFA (Vallimont et al., 2004). 
The increase in plasma BHB when citrus pulp partially replaced REC may reflect the metabolism of butyrate to BHB by the ruminal epithelium (Bergman, 1990).

The concentration of REC in the diet determined the proportion of daily intake in periods of the day and PS sorting behavior. High-starch diets exacerbated the refusal for long feed particles and in favor of short particles in the morning. Voelker and Allen (2003) observed that lactating cows rejected the fibrous portion of the diet when beet pulp replaced HMC in the diet, which was similar to the selective behavior observed in this experiment when REC was replaced with citrus pulp to reduce dietary starch content. Fine grinding of REC reduced sorting against NDF and rumination duration per day, suggesting some relationship between these variables, but starch sorting behavior did not differ. Fine grinding of REC also reduced TMR eating rate, without affecting meal pattern. Although REC particle size and proportion in the diet affected chewing and selective behavior, the effects were mostly driven by the variation in dietary proportion. The composition of the consumed diet in nutrients was not affected by the sorting behavior. The impact on lactating cows of varying the PS of REC when silage is stored for less than $200 \mathrm{~d}$ requires further evaluation.

\section{CONCLUSIONS}

Coarse grinding $(2,185 \mu \mathrm{m})$ of corn did not affect kernel storage as REC, and the grinding rate was 3 times faster than fine grinding $(1,591 \mu \mathrm{m})$. Ensiling mature flint corn for more than $200 \mathrm{~d}$ largely eliminated the effect of the PS of REC on intake, lactation performance, nutrient digestibility, ruminal fermentation profile, and chewing and sorting behaviors. Although the increase in feed efficiency suggests that FN was more fermentable in the rumen than CS, the effect of PS on cow productivity and behavior was minor. The concentration of starch in the diet affected ruminal fermentation profile and milk solids concentration, but had no effect on short-term performance and digestibility. Coarse grinding of REC may be a strategy to increase the rate of grinding to spare labor and energy during ensiling, without affecting cow performance, and may be advantageous when corn prices favor a high inclusion of the grain in the diet, by reducing the propensity to ruminal acidosis in relation to fine grinding.

\section{ACKNOWLEDGMENTS}

The authors are grateful to $\mathrm{CNPq}$ (National Research Council, Brasilia, Brazil) for funding the project (443894/2014-0, 304945/2012-9) and to the members of
Grupo do Leite of the University of Lavras for the help in data collection and animal care.

\section{REFERENCES}

Allen, M. S. 2000. Effects of diet on short-term regulation of feed intake by lactating dairy cattle. J. Dairy Sci. 83:1598-1624.

AOAC International. 2006. Official Methods of Analysis. 18th ed. AOAC International, Arlington, VA.

Arcari, M. A., C. M. M. R. Martins, T. Tomazi, and M. V. Santos. 2016. Effect of the ensiling time of hydrated ground corn on silage composition and in situ starch degradability. Braz. J. Vet. Res. Anim. Sci. 53:60-71

Baker, S., and T. Herrman. 2002. Evaluating particle size. Publication MF-2051. Kansas State Univ., Manhattan.

Baron, V. S., K. R. Stevenson, and J. G. Buchanan-Smith. 1986. Proteolysis and fermentation of corn-grain ensiled at several moisture levels and under several simulated storage methods. Can. J. Anim. Sci. 66:451-461.

Bergman, E. N. 1990. Energy contributions of volatile fatty acids from the gastrointestinal tract in various species. Physiol. Rev. 70:567-590.

Bitencourt, L. L. 2012. Substituição de milho moido por milho reidratado e ensilado ou melaço de soja em vacas leiteiras. $\mathrm{PhD}$ Thesis. Universidade Federal de Lavras, Lavras, Brazil.

Chaney, A. L., and E. P. Marbach. 1962. Modified reagents for determination of urea and ammonia. Clin. Chem. 8:130-132.

Chen, X. B., and M. J. Gomes. 1992. Estimation of microbial protein supply to sheep and cattle based on urinary excretion of purine derivatives: An overview of technical details. Int. Feed Res. Unit, Occasional Publ. Rowett Research Institute, Aberdeen, UK.

Correa, C. E. S., R. D. Shaver, M. N. Pereira, J. G. Lauer, and K. Kohn. 2002. Relationship between corn vitreousness and ruminal in situ starch degradability. J. Dairy Sci. 85:3008-3012.

Dehority, B. A. 1984. Evaluation of subsampling and fixation procedures used for counting rumen protozoa. Appl. Environ. Microbiol. $48: 182-185$

Dias, J. D. L., R. B. Silva, T. Fernandes, E. F. Barbosa, L. E. C. Graças, R. C. Araujo, R. A. N. Pereira, and M. N. Pereira. 2018. Yeast culture increased plasma niacin concentration, evaporative heat loss, and feed efficiency of dairy cows in a hot environment. J. Dairy Sci. 101:5924-5936.

Ewing, D. L., D. E. Johnson, and W. V. Rumpler. 1986. Corn particle passage and size reduction in the rumen of beef steers. J. Anim. Sci. 63:1509-1515.

Fernandes, T., C. L. S. Ávila, M. N. Pereira, and L. F. Ferraretto. 2018. Effect of washing method, grinding size, and the determination of an indigestible fraction on in situ degradation of starch in mature corn grain. J. Dairy Sci. 101:9052-9057.

Ferraretto, L. F., P. M. Crump, and R. D. Shaver. 2013. Effect of cereal grain type and corn grain harvesting and processing methods on intake, digestion, and milk production by dairy cows through a meta-analysis. J. Dairy Sci. 96:533-550.

Firkins, J. L., M. L. Eastridge, N. R. St-Pierre, and S. M. Noftsger. 2001. Effects of grain variability and processing on starch utilization by lactating dairy cattle. J. Anim. Sci. 79:E218-E238.

Fredin, S. M., L. F. Ferraretto, M. S. Akins, S. J. Bertics, and R. D. Shaver. 2015. Effects of corn-based diet starch concentration and corn particle size on lactation performance, digestibility, and bacterial protein flow in dairy cows. J. Dairy Sci. 98:541-553.

Fredin, S. M., L. F. Ferraretto, M. S. Akins, P. C. Hoffman, and R. D. Shaver. 2014. Fecal starch as an indicator of total-tract starch digestibility by lactating dairy cows. J. Dairy Sci. 97:1862-1871.

Galyean, M. L., D. G. Wagner, and F. N. Owens. 1979. Corn particle size and extent of digestion by steers. J. Anim. Sci. 49:204-210.

Goodrich, R. D., F. M. Byers, and J. C. Meiske. 1975. Influence of moisture concentration, processing and reconstitution on the fermentation of corn grain. J. Anim. Sci. 41:876-881. 
Hall, M. B. 2009. Determination of starch, including maltooligosaccharides, in animal feeds: Comparison of methods and a method recommended for AOAC collaborative study. J. AOAC Int. 92:42-49.

Headley, V. E., and H. B. Pfost. 1968. A comminution equation relating energy to surface area by log-probability method. Trans. ASAE 11:331-334.

Heron, S. J. E., R. A. Edwards, and P. McDonald. 1986. Changes in the nitrogenous components of gamma-irradiated and inoculated ensiled ryegrass. J. Sci. Food Agric. 37:979-985.

Hoffman, P. C., N. M. Esser, R. D. Shaver, W. K. Coblentz, M. P. Scott, A. L. Bodnar, R. J. Schmidt, and R. C. Charley. 2011. Influence of ensiling time and inoculation on alteration of the starchprotein matrix in high-moisture corn. J. Dairy Sci. 94:2465-2474.

Junges, D., G. Morais, M. H. F. Spoto, P. S. Santos, A. T. Adesogan, L. G. Nussio, and J. L. P. Daniel. 2017. Short communication: Influence of various proteolytic sources during fermentation of reconstituted corn grain silages. J. Dairy Sci. 100:9048-9051.

Knowlton, K. F., B. P. Glenn, and R. A. Erdman. 1998. Performance, ruminal fermentation, and site of starch digestion in early lactation cows fed corn grain. J. Dairy Sci. 81:1972-1984.

Kung, L., Jr., R. D. Shaver, R. J. Grant, and R. J. Schmidt. 2018. Silage review: Interpretation of chemical, microbial, and organoleptic components of silages. J. Dairy Sci. 101:4020-4033.

Lammers, B. P., D. R. Buckmaster, and A. J. Heinrich. 1996. A simple method for the analysis of particle sizes of forages and total mixed rations. J. Dairy Sci. 79:922-928.

Mullins, C. R., L. K. Mamedova, M. J. Brouk, C. E. Moore, H. B. Green, K. L. Perfield, J. F. Smith, J. P. Harner, and B. J. Bradford. 2012. Effects of monensin on metabolic parameters, feeding behavior, and productivity of transition dairy cows. J. Dairy Sci. 95:1323-1336.

National Research Council. 2001. Nutrient Requirements of Dairy Cattle. 7th rev. ed. Natl. Acad. Press, Washington, DC.

Nozière, P., W. Steinberg, M. Silberberg, and D. P. Morgavi. 2014 Amylase addition increases starch ruminal digestion in first-lactation cows fed high and low starch diets. J. Dairy Sci. 97:2319-2328.

Oba, M., and M. S. Allen. 2003a. Effects of corn grain conservation method on feeding behavior and productivity of lactating dairy cows at two dietary starch concentrations. J. Dairy Sci. 86:174183.

Oba, M., and M. S. Allen. 2003b. Effects of corn grain conservation method on ruminal digestion kinetics for lactating dairy cows at two dietary starch concentrations. J. Dairy Sci. 86:184-194.

Reis, R. B., F. San Emeterio, D. K. Combs, L. D. Satter, and H. N. Costa. 2001. Effect of corn particle size and source on performance of lactating cows fed direct-cut grass-legume forage. J. Dairy Sci. 84:429-441.

Rémond, D., J. I. Babrera-Estrada, M. Champion, B. Chauveau, R. Coudure, and C. Poncet. 2004. Effect of corn particle size on site and extent of starch digestion in lactating dairy cows. J. Dairy Sci. 87:1389-1399.

Salvati, G. G. S., N. N. Morais Júnior, A. C. S. Melo, R. R. Vilela, F. F. Cardoso, M. Aronovich, R. A. N. Pereira, and M. N. Pereira. 2015. Response of lactating cows to live yeast supplementation during summer. J. Dairy Sci. 98:4062-4073.

San Emeterio, F., R. B. Reis, W. E. Campos, and L. D. Satter. 2000 Effect of coarse or fine grinding on utilization of dry or ensiled corn by lactating dairy cows. J. Dairy Sci. 83:2839-2848.

Seo, S., L. O. Tedeschi, C. Lanzas, C. G. Schwab, and D. G. Fox. 2006. Development and evaluation of empirical equations to predict feed passage rate in cattle. Anim. Feed Sci. Technol. 128:67-83.

Taylor, C. C., and M. S. Allen. 2005. Corn grain endosperm type and brown midrib 3 corn silage: Site of digestion and ruminal digestion kinetics in lactating cows. J. Dairy Sci. 88:1413-1424.

Vallimont, J. E., F. Bargo, T. W. Cassidy, N. D. Luchini, G. A. Broderick, and G. A. Varga. 2004. Effects of replacing dietary starch with sucrose on ruminal fermentation and nitrogen metabolism in continuous culture. J. Dairy Sci. 87:4221-4229.

Voelker, J. A., and M. S. Allen. 2003. Pelleted beet pulp substituted for high-moisture corn: 1. Effects on feed intake, chewing behavior, and milk production of lactating dairy cows. J. Dairy Sci $86: 3542-3552$

Warner, A. C. 1962. Enumeration of rumen microorganisms. J. Gen. Microbiol. 28:119-128. 


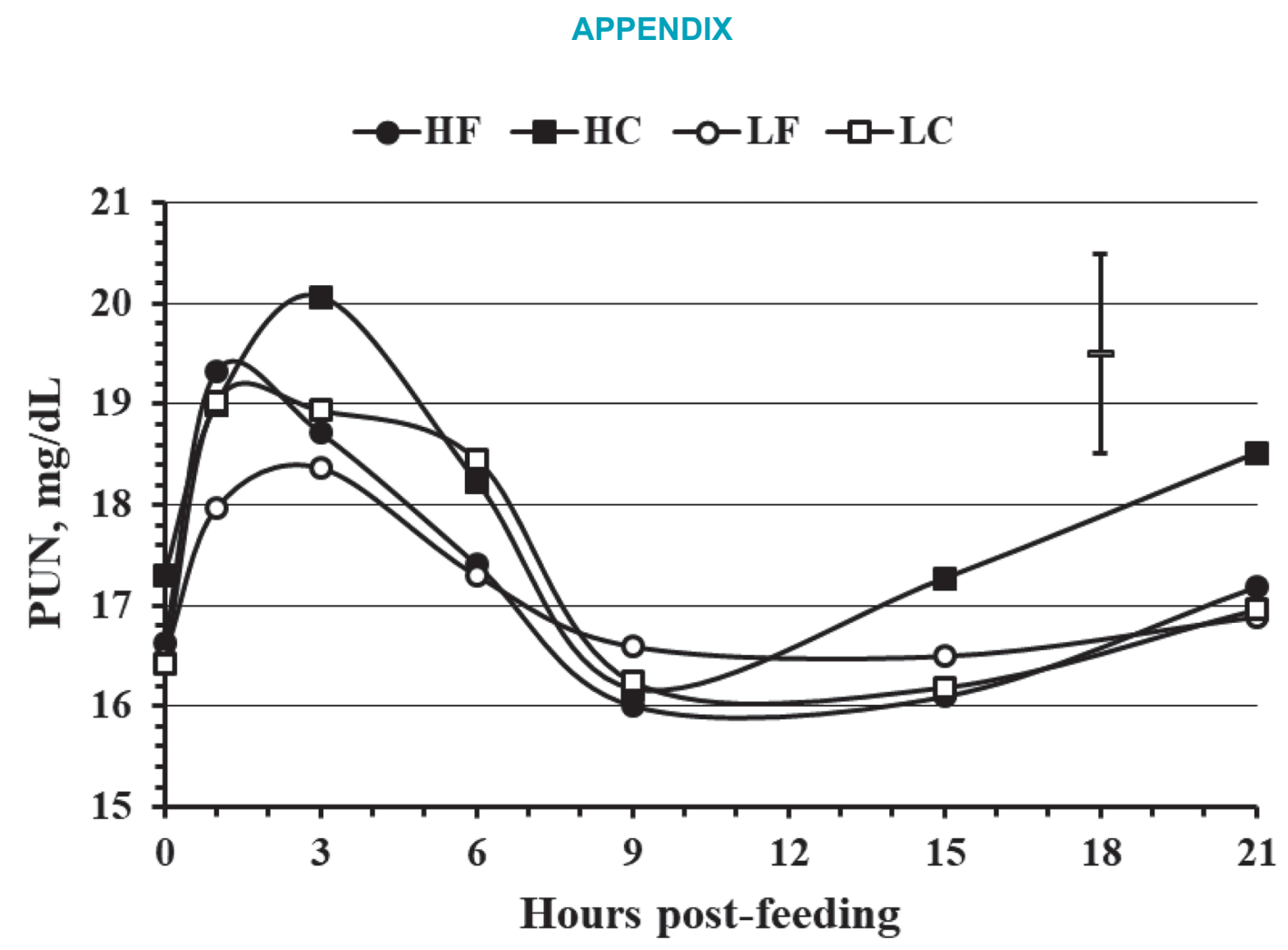

Figure A1. Plasma urea-N (PUN) in cows that were fed the following treatments: high-starch and fine-ground REC (HF), high-starch and coarse-ground REC (HC), low-starch and fine-ground REC (LF), and low-starch and coarse-ground REC (LC). $P=0.44$ for starch, $P=0.32$ for particle size, $P=0.67$ for the interaction starch $\times$ particle size, $P<0.01$ for hour postfeeding, $P=0.92$ for starch $\times$ hour, $P=0.96$ for particle size $\times$ hour, and $P=0.88$ for starch $\times$ particle size $\times$ hour. Vertical line represents \pm SEM. Cows were fed at 0700 h. REC $=$ rehydrated and ensiled corn. 